DOI https://doi.org/10.30525/978-9934-588-81-5-2.39

\title{
MONITORING PEOPLE'S FUNCTIONAL STATE BY ELECTROSKIN CHARACTERISTICS
}

\author{
Strakhova O.P. \\ Candidate of Biological Sciences, \\ Assistant at the Department of Medical and Biological Informatics and NT \\ Zaporizhzhia State Medical University \\ Ryzhov O. A. \\ Doctor of Pharmaceutical Sciences, Professor, \\ Head of the Department of Medical and Biological Informatics and NT \\ Zaporizhzhia State Medical University \\ Zaporizhzhia, Ukraine
}

The digitalization of society in the world has been slow, but some events have been able to accelerate it, intensifying the need to introduce distance learning, distance working into human life as soon as possible. During the pandemic, which lasted more than six months, people's physical activity was significantly limited. In the vast majority of people, the base of work and study have moved to the virtual world, and take place remotely, based on the use of information and communication computer networks. The environment of ergatic computerized systems is reduced to the boundaries of the room, where people are almost around the clock. At the same time their functional state changes. As this happens all the time, over time, persistent functional abnormalities appear that can lead to future illnesses.

To prevent this, especially among students [1], it is necessary to have an easy-to-use functional condition monitoring system that informs about changes in the condition and helps the user to know that the functional systems of his/her body are working with overload for some time, and measures should be taken to correct this situation.

There is a solution to the problem in the form of an inexpensive and easy-to-use automated system for monitoring the functional state of persons in the ergatic system based on the registration of electrodermal characteristics, and their changes, of microzones corresponding to the locations of some acupuncture corporal or auricular points. The system is built on the «Phenomenon of the average stability of the electrodermal characteristics» [2]. The system includes a measuring device in the form of a bracelet or earphone, a Bluetooth module for transmitting parameters to a gadget or 
computer, and a program that detects critical changes in the state of the microzone. Measurements are carried out at predetermined time intervals. Program forms a database and places all measurement results in it in chronological order. Relative changes in the persons' functional state are determined as a difference with previous measurements. Also, the program determines the general changes in the parameters of all monitored microzones relative to each other, thus creating a temporal map of changes in the functional state of a person. Changes in the functional state of the student are determined by the general change in the conductivity levels of the controlled points, and are understood as requiring correction if they go beyond the calculated confidence intervals for each controlled point.

The system makes it possible to track both generalized changes in the functional state of a person and for each point, which, according to the theory of acupuncture, describes the state of a particular organ or functional system, separately.

Accumulated by the proposed system for some time information about changes in the functional state of a person, by analogy with Holter monitoring, will make a map or gallery of parameters of the human condition at various loads, rest, walks and more.

This solution makes it possible to observe not only the state of the cardiovascular system, but also the relative changes in the functional state of other human body organs and systems, without the use of cumbersome and expensive diagnostic methods.

\section{References:}

1. Сергеев С. Ф. Образование в глобальных техногенных средах: возможности и ограничения. Образовательные ресурсы и технологии. 2012. № 1. C. 21-32.

2. Страхова О. П., Рыжов А. А. Явление стабильности средней величины электрокожной проводимости по постоянному току в акупунктурных «точках-источниках меридианов» на теле человека. А. с. № 56102 Украина, ГСАП; заявл. 19.06.2014 № 56504; опубл. 18.08.2014. 